\title{
ESTABLISHMENT AND MANAGEMENT OF 'GRASSLANDS MAKU' LOTUS IN ACID, LOW- FERTILITY TUSSOCK GRASSLANDS
}

R. S. Scott and E. G. Milis

Invermay Agricultural Research Centre, Mosgiel

\section{Abstract}

'Grasslands Maku' lotus (Lotus pedunculatus Cav.) is a legume with high potential for the development of acid $(\mathrm{pH}<5.2)$, phosphate-deficient soils which represent approximately half of the area of the tussock grasslands of New Zealand. Experiments at $a$ number of sites have shown Maku lotus to produce about three times the yields from clovers under similar levels of superphosphate topdressing. The superiority of lotus is attributed to its greater P efficiency on acid soils high in exchangeable Al. Maku can be established with low topdressing $(100 \mathrm{~kg}$ superphosphate/ha $)$ Because of its responsiveness to additional $\mathrm{P}$ (and given more realistic seed prices), it lends itself to low-cost development with low fertilizer input followed by intensification of the programme by topdressing as the development generates capital.

Good establishment can be obtained from oversowing at 2 to 3 $\mathrm{kg}$ seed/ha and allowing time for increased density via rhizome spread. Rhizome development can be enhanced by deferring grazing in the establishment year until April following spring oversowing. While lime $(0.5 \mathrm{t} / \mathrm{ha})$ increases establishment, the economics of liming as a means of economizing in seed is doubtful.

When the lotus was allowed to regrow to $15 \mathrm{~cm}$, grazing with sheep to $2.5 \mathrm{~cm}$ compared with grazing by cattle to $7.5 \mathrm{~cm}$ did not affect yields. Evidence under farm conditions suggests lotus will persist on acid soils under close and continuous grazing.

\section{INTRODUCTION}

DEVELOPMENT of both arable and non-arable land in New Zealand has been successfully and almost exclusively based on the introduction of white, red, alsike and subterranean clover-s. Technology enabling successful establishment of these plants is well developed and there are few examples of failure, Attention of research work- 
TABLE 1: LOTUS AND CLOVER YIELDS THREE YEARS AFTER OVERSOWING ON A RANGE OF TUSSOCK GRASSLAND SITES (kg DM/ha)

\begin{tabular}{|c|c|c|c|c|c|c|c|}
\hline Soil Type & District & $\begin{array}{l}\text { Altitude } \\
(m \text { a.s.l. })\end{array}$ & $p H$ & $\begin{array}{l}\text { Maku } \\
\text { Lotus }\end{array}$ & $\begin{array}{l}\text { Huia } \\
\text { White } \\
\text { Clover }\end{array}$ & $\begin{array}{c}\text { Lotus: } \mathbf{Q} \text { over } \\
\text { Ratio }\end{array}$ & Reference \\
\hline Waipori & Waipori & 610 & 4. 6 & 4990 & 1520 & 3.3 & Lowther (Unpubl. data) \\
\hline Waipori & Berwick & 420 & 4.6 & 1090 & 420 & 2.6 & Lowther (Unpubl. data) \\
\hline Mahinerangi & Waiora Farm & 550 & 4.6 & 3080 & 1120 & 2.8 & Scott (Table 6) \\
\hline Teviot & Rocklands Stn & 800 & 4.9 & 930 & 120 & 7.7 & Lowther (Unpubl. data) \\
\hline Kaikoura & Danseys Pass & 914 & 5.0 & 1690 & 580 & 2.9 & Greenwood (Unpubl. data) \\
\hline Tengawai & Danseys Pass & 609 & 5.5 & 1670 & 1130 & 1.5 & Greenwood (Unpubl. data) \\
\hline Kirkliston & Tara Hills* & 475 & 5.5 & 4480 & 3020 & 1.5 & Musgrave (1977) \\
\hline
\end{tabular}

*Sunny face; trial on shady face failed owing to frost heave. 
ers in New Zealand is turning increasingly to a search for legumes other than clovers to enable the development of land on which clovers do not thrive.

This paper reports results of experiments on acid soils with 'Grasslands Maku' lotus (Lotus pedunculatus Cav.) which was recognized by Lowther (1977), Musgrave (1977) and Nordmeyer and Davis (1977) as having an important role to play on such soils under tussock. These soils comprise about half of the 5.2 million ha of tussock grasslands in New Zealand. About 1.8 million ha have $\mathrm{pH}$ values in the range 5.0 to 5.2 and 1.0 million ha have $\mathrm{pH}$ values below 5.0

\section{GROWTH ON ACID SOILS}

Several workers have shown on low-fertility soils of $\mathrm{pH}$ around 5.0 or less that Maku lotus (lotus) outyields Huia white clover (clover) by about 3: 1 . Yields presented in Table 1 were recorded in the third year of each experiment when lotus was well established. While for conformity of presentation results are given from trestments receiving $300 \mathrm{~kg}$ superphosphate/ha, the yield advantage of lotus was apparent at low levels of superphosphate (100 $\mathrm{kg} / \mathrm{ha}$ ) (Lowther, 1977) . The Waiora experiment was topdressed with $300 \mathrm{~kg}$ superphosphate at sowing and $100 \mathrm{~kg} / \mathrm{ha} / \mathrm{yr}$ thereafter.

Assuming $60 \%$ feed utilization and an annual feed allowance of $550 \mathrm{~kg} \mathrm{DM} / \mathrm{SU}$, the potential increase in carrying capacity following lotus oversowing based on the legume yields alone is 1 to $5.5 \mathrm{SU} / \mathrm{ha}$. Compared with clover, lotus would enable an additional 0.75 to $3.75 \mathrm{SU} /$ ha to be carried.

Reasons for the higher yields from lotus compared with clover on these soils lie in the greater ability of lotus to take up P from the soil (Brock, 1973) and the inability of clover to tolerate high levels of exchangeable $\mathrm{Al}$ in the soil and the effect of this on $\mathrm{P}$ absorption (Nordmeyer and Davis, 1977; Scott and Lowther. 1980). The latter authors grew lotus and clovers in alternate rows in undisturbed turfs of a low fertility Waipori soil (a yellowbrown earth, $\mathrm{pH} 4.6$ ). Roots of the species were either separated by partitions or allowed to intermingle. Where roots mingled, yields of lotus increased and those of clover decreased compared with yields of each species grown with roots separated (Table 2 (a)). Concentrations of $\mathrm{P}$ (the deficient nutrient) in herbage followed the same pattern (Table 2 (b)). Additions of a high rate of $\mathrm{P}$ reduced the intensity of competition. 
TABLE 2: ROOT COMPETITION BETWEEN MAKU LOTUS AND HUIA WHITE CLOVER IN UNDISTURBED TURFS OF A WAIPORI SOIL (pH 4.6) ON DAY 130

(Scott and Lowther, in press)

\begin{tabular}{lccc}
\hline & \multicolumn{2}{c}{ Roots of Species } \\
& Separafe & Mingling \\
\hline (a) Dry matter yields (g DM/turf): & & & \\
Clover & 1.188 & & 0.858 \\
Lotus & 3.199 & 5.099 \\
L S D ( $5 \%$ ) & & 0.921 & \\
(b) Herbage P concentrations (\% D.M.): & & \\
Clover & 0.185 & & 0.150 \\
Lotus (5\%) & 0.105 & 0.130 \\
LSD (5\%) & & 0.024 & \\
\hline
\end{tabular}

In a subsequent experiment (Scott, unpublished data) where a high rate of $\mathrm{P}(100 \mathrm{~kg} / \mathrm{ha})$ was applied, yields of clover increased and those of lotus decreased to the point where clover outyielded lotus. Concentrations of $\mathrm{Al}$ were $51 \mathrm{ppm}$ in lotus and $122 \mathrm{ppm}$ in clover, which for the latter species was above the toxicity threshold (Andrew et al., 1973). As high levels of exchangeable soil $\mathrm{Al}$ are known to reduce absorption and translocation of $\mathrm{P}$, it seems reasonable to assume that lotus is "Al tolerant" and clover "Al intolerant" and that this difference considerably influenced their relative abilities to complete for scarce $\mathrm{P}$.

\section{PHOSPHATE REQUIREMENTS}

While it has been shown that lotus is a more $\mathrm{P}$ efficient legume than clover on very acid soils, it nevertheless requires superphosphate topdressing for its establishment and survival. This is demonstrated by results of an experiment at Mt Dasher Station on a yellow-brown earth ( $\mathrm{pH} 4.9$, Olsen P 9) at an altitude of $700 \mathrm{~m}$ (a.s.l.). Total lotus dry matter yields over the first two years (Table 3) show that lotus failed to establish satisfactorily in the absence of applied $\mathrm{P}$, but that an initial dressing of $10 \mathrm{~kg} \mathrm{P} / \mathrm{ha}$ ensured its survival and some production (equivalent to about 2 $\mathrm{SU} / \mathrm{ha}$ in the second year). Results also show that lotus is very responsive to additional $\mathrm{P}$, and where light (10 to $20 \mathrm{~kg} \mathrm{P} / \mathrm{ha}$ ) dressings are applied initially a repeat dressing in the second year doubled yields. In land development programmes this would allow low cost development followed by an intensification of development as the programmes generate capital.

Attention has been drawn to the effects of competition between lotus and clover. Field results of Lowther (1977) demonstrated 


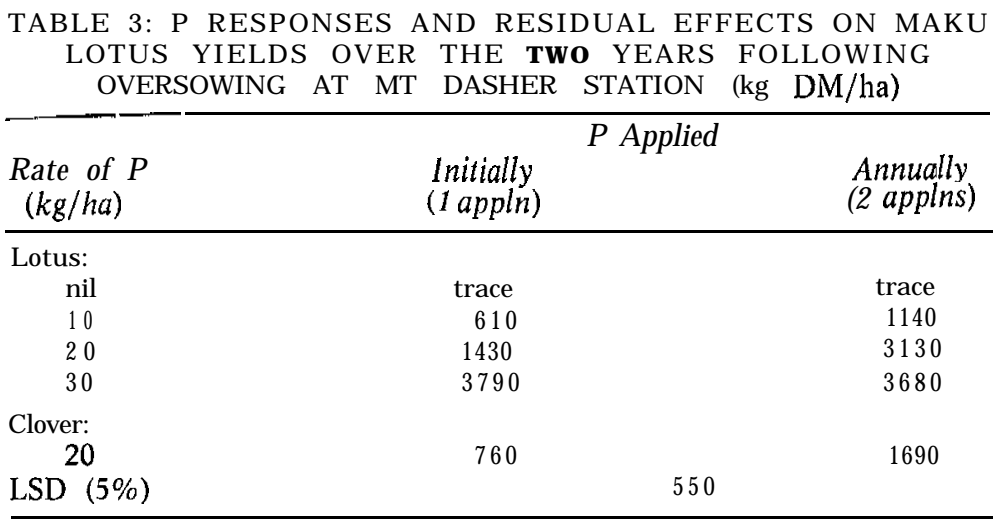

that yields of a mixture were less than yields from lotus alone. Lower yields from the mixture probably result from the fact that where clover is growing (albeit low yielding) it is nevertheless absorbing $\mathrm{P}$ which would otherwise be available to the more productive lotus. Hence, when deciding on areas to oversow, it would be advisable to avoid those where clover is present. Also it is recommended that no clover be included with lotus oversowings.

On soils of $\mathrm{pH} 5.6$ or greater (and presumably lower levels of exchangeable $\mathrm{Al}$ ), and high levels of available $\mathrm{P}$ compared with those of soils discussed above, Brock and Charlton (1978) in the Manawatu and Scott (1978, 1979) at Invermay have found difficulty in retaining lotus in swards where white clover is present. Brock and Charlton (1978) considered this to be due to the inability of lotus to withstand close grazing and Sheath (1978) has recommended the selection of a lotus cultivar with improved regrowth characteristics to enable lotus to be retained in a mixed pasture. It is interesting to speculate (in view of results on acid soils) whether or not dominance of white clover over lotus under these conditions is attributable to edaphic conditions favouring clover growth rather than to the inability of lotus to survive under close and continuous grazing.

\section{EFFECTS OF LIME AND SEEDING RATES}

Lowther (1977) showed no improvement in lotus establishment following lime-pelleting inoculated seed compared with inoculation using a $10 \%$ (w.v.) gum arabic adhesive, For some as yet unexplained reason, he found that lime broadcast $(1.25 \mathrm{t} / \mathrm{ha})$ at oversowing increased nodulation and establishment. Because of 

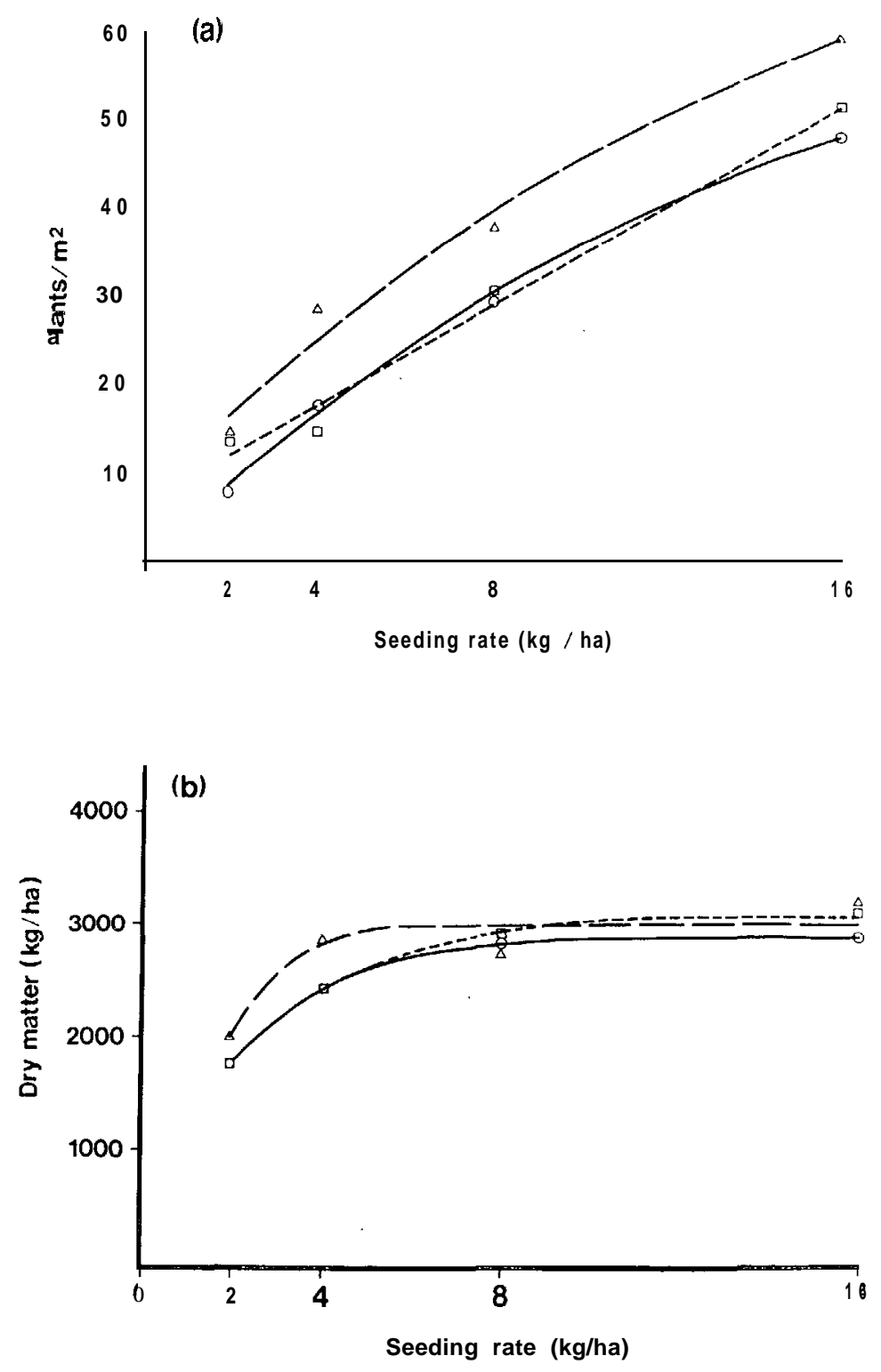

FIG. 1: Fitted curves for (a) plant counts (b) DM yields of Maku lotus as affected by seeding rates and lime application at sowing. circles $=$ no lime, triangles $=0.5 \mathrm{t}$ lime $/ \mathrm{ha}$, squares $=1.0 \mathrm{t}$ lime $/ \mathrm{ha}$. 
the high cost of lotus seed, an experiment was conducted at the Waiora Hill Country Research farm near Mosgiel to determine minimum rates of broadcast lime as a means of reducing seeding rates. Snow tussock was first burnt and the experiment sown in August 1977 on a Mahinerangi yellow-brown earth ( $\mathrm{pH} 4.5)$ low in available $\mathrm{P}($ Olsen $\mathrm{P}=9)$. It compared 3 levels of lime (nil, 0.5 and $1 . \mathrm{Ot} / \mathrm{ha})$ and 4 seeding rates of lotus $(2,4,8$ and $16 \mathrm{~kg}$ viable seed/ha).

Results (Fig. 1) showed a significant increase $(P<0.05)$ in the number of plants established following application of $0.5 \mathrm{t}$ lime/ha, but no benefit from applying $1.0 \mathrm{t} / \mathrm{ha}$. The fitted curves (Fig. 1 (a)) suggest a similar number of plants were established by applying $0.5 \mathrm{t}$ lime/ha with $2 \mathrm{~kg}$ seed/ha as from sowing $4 \mathrm{~kg}$ seed/ha without lime. Significant but small differences in dry matter yields between no lime and both limed treatments were recorded in the establishment year (30 vs. $60 \mathrm{~kg} \mathrm{DM} / \mathrm{ha}$ ) and the second year (1210 vs. $1450 \mathrm{DM} / \mathrm{ha})$. These differences were due to the greater number of plants established on limed treatments; lime did not influence plant growth. In the third year, lime did not affect yields (Fig. 1 (b)) and there was a significant (quadratic) response to increasing seeding rates. This suggests that yields between seeding rates were becoming closer with time,

Sampling the underground organs of lotus in the second winter following sowing (Table 4) showed greater weights of crowns and roots on limed treatments and higher seeding rate treatments, which would be a reflection largely of the greater number of older (initially established) plants on these treatments. Rhizomes, which according to Sheath (1978) are the principal contributors to above-ground growth, did not differ in weight on limed treatments or between seeding rates. This, then, would explain (at least in part) the absence of responses to lime and the relatively small difference in yields between widely different rates in the subsequent (third) year.

TABLE 4: EFFECTS OF LIME AND SEEDING RATES ON THE WEIGHT OF UNDERGROUND ORGANS OF MAKU LOTUS IN THE SECOND WINTER FOLLOWING OVERSOWING (kg DM/ha)

\begin{tabular}{lrrrrrrrrr}
\hline Component Lime (t/ha) & LSD & (5\%) & Seeding & Rate & $(\mathrm{kg} / \mathrm{ha})$ & LSD (5\%) \\
& 0 & 0.5 & 1.0 & & 2 & 4 & 8 & 16 & \\
\hline Crowns & 51 & 84 & 108 & 30 & 51 & 84 & 96 & 98 & 35 \\
Roots & 84 & 110 & 111 & 40 & 63 & 102 & 103 & 140 & 47 \\
Rhizomes & 35 & 58 & 34 & 28 & 35 & 53 & 41 & 40 & 33 \\
\hline
\end{tabular}


From the practical viewpoint, results indicate that on extremely acid soils liming at $0.5 \mathrm{t} / \mathrm{ha}$ may enable a reduction in seeding rate (e.g., $2 \mathrm{~kg} / \mathrm{ha}$ in place of $4 \mathrm{~kg} / \mathrm{ha}$ without lime) which would be beneficial during the initial few years following sowing. The advisability of such a practice must be determined by the individual farmer on the basis of current costs of seed and applying lime.

\section{GRAZING MANAGEMENT DURING ESTABLISHMENT}

A study on the Waiora farm was commenced in 1977 comparing the effects of grazing frequency with sheep from the time of oversowing in October until immediately prior to frost in the first autumn. Results (Table 5) show a marked increase in numbers of rhizomes and rhizome buds as grazing frequency was de; creased and deferred until the end of the first growing season. Spring herbage yields did not reflect significantly these increases in rhizome development. It is possible that experimental variability ( $\mathbf{C V}=44 \%)$ obscured detection of any herbage response, or that no response occurred because stored carbohydrates in the crown and taproots of established plants were utilized in providing the energy for increased rhizome development, with insufficient remaining to stimulate spring growth. The longer term effects of the increased rhizome development were not measured as the design of the experiment was altered after the spring grazing.

TABLE 5: EFFECTS OF GRAZING FREQUENCY IN THE ESTABLISHMENT YEAR ON NUMBERS OF RHIZOMES AND RHIZOME BUDS IN LOTUS AND ON SUBSEQUENT SPRING HERBAGE YIELDS (kg DM/ha)

\begin{tabular}{lccc}
\hline Grazing Frequency & Rhizomes $/ \mathrm{m}^{2}$ & Rhizome Buds $/ \mathrm{m}^{2}$ & $\begin{array}{c}\text { Herbage Yields } \\
(23.11 .78)\end{array}$ \\
\hline 4 grazings (Dec, Feb, Mar, May) 60 & 290 & 640 \\
2 grazings (Mar, May) & 350 & 1420 & 710 \\
1 grazing (May) & 660 & 2500 & 770 \\
Significant effects & $* *$ & $* *$ & n.s. \\
LSD (5\%) & 240 & 1530 & 170 \\
\hline
\end{tabular}

It seems probable that the increased sward density resulting from a greater number of emerging rhizome buds together with the major contribution rhizome shoots make to overall aboveground production will result in increased production. Thus, it is recommended that grazing be deferred in the establishment year from oversowing until shortly before frosting about April. 


\section{EFFECTS OF SHEEP AND CATTLE GRAZING}

Because of the findings of Brock and Charlton (1978) in the Manawatu which suggested that lotus would not withstand close grazing in mixtures under high fertility, the effects of grazing to $2.5 \mathrm{~cm}$ with sheep and to $7.5 \mathrm{~cm}$ with cattle were compared. Treatments represent the two alternatives available to farmers. Regrowth of lotus was to $\mathbf{1 5} \mathrm{cm}$ using cattle-grazed lotus as a standard and all treatments were grazed at the same time. Three grazings were obtained each season. The experiment was conducted on the plots used for the grazing management study described previously, with treatments re-randomized.

Yields from cattle-grazed lotus (Table 6) did not differ significantly from those of sheep-grazed lotus. Of interest was the small increase in clover yields from the second to third year and the threefold increase in lotus yields. This suggests that the persistency of lotus was not adversely affected by grazing to $2.5 \mathrm{~cm}$.

TABLE 6: EFFECT OF CATTLE AND SHEEP GRAZING ON YIELDS OF MAKU LOTUS AND HUIA WHITE CLOVER AT WAIORA TWO AND THREE YEARS FOLLOWING OVERSOWING (kg DM/ha)

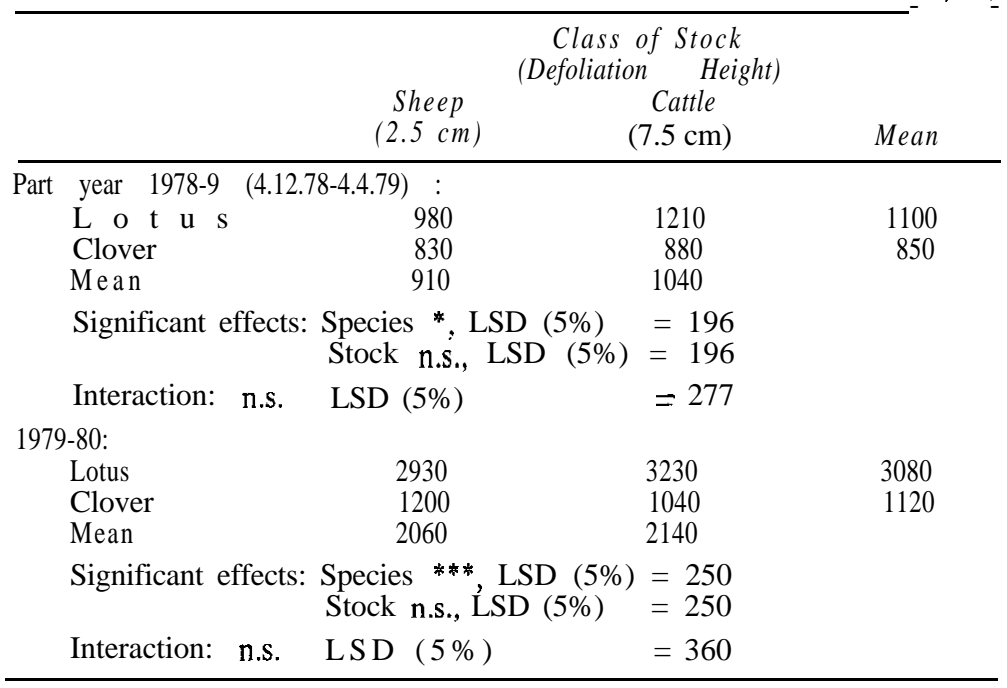

The effects of close and continuous grazing have not been examined experimentally. There are, however, examples of this on two farmer properties. One was at Berwick $(\mathrm{pH}$ 4.6) where fences around a Maku lotus trial (laid down in 1969) were removed in 
1972. The block, including the trial site, was oversown with a clover/grass mixture in 1971 and since then has been regularly topdressed with superphosphate. Over tht S-year period up to 1980 it has been grazed with sheep and cattle under both close and lenient grazing. In 1980, eleven years after over-sowing, lotus comprised $60 \%$ of the legume. Similar evidence pointing to the persistency of lotus on acid tussock grassland soils can also be seen on an old trial site on the property of L. Coutts, inland from Palmerston, where Maku lotus was sown by S. M. Stockdill in 1974 and is persisting well under close grazing.

\section{THE PLACE OF LOTUS IN TUSSOCK GRASSLAND FARMING}

Because of the relatively recent release of the "cultivar Maku lotus and the present high price of seed, few farmers have oversown it. A programme of development described by P. J. Wardell of Mt Dasher Station to the 1980 High Country Field Day illustrates the likely use of Maku lotus. On this 8000 ha property, some 1600 ha of lower country (less than $600 \mathrm{~m}$ a.s.l.) has been successfully oversown in a clover/grass mixture and subdivided into 120 ha blocks. About $10000 \mathrm{SU}$ are carried, and fairly intensive mob stocking with 4800 ewes in a mob is practised.

The present development programme depends heavily on the use of Maku lotus on the more acid soils ( $900 \mathrm{~m}$ a.s.l.) so that stock (particularly cattle) can be carried in summer/autumn to allow the lower clover country to be spelled for ewe flushing and wintering. The programme has been commenced with the successful establishment of lotus on 400 ha sown with $2 \mathrm{~kg}$ seed/ha and $100 \mathrm{~kg}$ superphosphate/ha. Low maintenance topdressing ( $\mathrm{ca}$. $100 \mathrm{~kg}$ superphospate biennially) will be applied. Mr Wardell believes (on the basis of research evidence) that lotus represents the key to successful expansion as he foresees financial returns on large amounts of maintenance topdressing required by grass/ clover difficult to find.

\section{CONCLUSIONS}

Clearly Maku lotus has tremendous potential for the development of large areas of the tussock grasslands of New Zealand. It is not recommended as an alternative to white clover on soils of moderate acidity, but as the most productive legume available for use on acid, low-fertility soils where white clover does not thrive without heavy topdressing. 


\section{ACKNOWLEDGEMENTS}

The authors wish to acknowledge assistance in the field of A. K. McLaren and L. Mitchell and to thank P. Greenwood and Dr W. L. Lowther for permission to use their unpublished data.

\section{REFERENCES}

Andrew, C. S.; Johnson, A. D.; Sandland, R. L., 1973. A mt. J. agric. Res., 24: $325-39$.

Brock, J. L., 1973. N.Z. Il agric. Res., 16: 483-91

Brock, J. L.; Charlton, J. F. L., 1978. Proc, N.Z. Grassld A ss., 39: 121-9.

Lowther, W. L., 1977. Proc. N .Z. Grassld A ss., 38: 133-9.

Musgrave, D. I 1977. Proc. N.Z. Grassld A SS., 38: 126-32.

Nordmeyer, A. H.; Davis, M R., 1977. Proc. N .Z. Grassld A ss., 38: 119-25.

Scott, R. S., 1978. A. Rep. Res. Div. 1977/78. Ministry of Agriculture and Fisheries.

1979. Res. Div. A. Rep., Southern South Island Region, 1978/79. Ministry of Agriculture and Fisheries.

Scott, R. S.; Lowther, W. L., 1980. N.Z. $/ l$ agric. Res. (in press).

Sheath, G. W., 1978. Ph.D. thesis, Massey University. 